Volume 2, Nomor 2, Desember 2021

\title{
ANALISIS KESALAHAN SINTAKSIS DALAM BERITA ONLINE \\ TRADISI SUNATAN UNIK DI KLATEN, BOCAH DIARAK DAN \\ DIMANDIKAN DI SENDANG DI SOLOPOS.COM
}

Imron Niatul Nur Hasanah, ${ }^{1}$ Wahyu Nur Khasanah ${ }^{2}$, Ghoni Miatin ${ }^{3}$

\begin{abstract}
ABSTRAK
Bahasa adalah alat yang digunakan untuk berkomunikasi dan menyampaikan pendapat antara satu orang dengan orang lain. Seiring dengan berkembangnya waktu, media untuk menyampaikan bahasa semakin berkembang, hal ini ditandai dengan munculnya media online. Untuk menyampaikan informasi melalui media online penulis harus mempergunakan kaidah kebahasaan secara baik dan benar. Tetapi kadangkala penulisan berita online masih memiliki banyak kesalahan, misalnya berita online yang diterbitkan oleh Suarajatim.id dengan judul Gunung semeru, kisah legenda, misteri, hingga kisah pendakian yang ditulis oleh Muhammad Taufik. Tujuan dari penelitian ini ialah mendiskripsikan kesalahan berbahasa tataran sintaksis. Penelitian ini menggunakan metode deskriptif kualitatif. Hasil dari penelitian ini yaitu masih ditemukannya kesalahan sintaksis seperti penulisan huruf kapital, tanda baca, tanda hubung, dan kesalahan sintaksis lainnya.
\end{abstract}

Kata Kunci: majalah online, analisis kesalahan sintaksis

\begin{abstract}
Language is a tool used to communicate and express opinions between one person and another. Along with the development of time, the media to convey language is growing, this is marked by the emergence of online media. To convey information through online media, the author must use linguistic rules properly and correctly. But sometimes online news writing still has many mistakes, for example online news published by Suarajatim.id with the title Mount Semeru, legend stories, mysteries, to climbing stories written by Muhammad Taufik. The purpose of this study is to describe language errors at the syntactic level. This study used descriptive qualitative method. The results of this study are that there are still syntactic errors such as writing capital letters, punctuation marks, hyphens, and other syntactic errors.
\end{abstract}

Keywords: online magazine, syntactic error analysis

\footnotetext{
${ }^{1}$ Fakultas Adab dan Bahasa, Universitas Islam Negeri Raden Mas Said Surakarta. Email:imronniatulnur@gmail.com

${ }^{2}$ Fakultas Adab dan Bahasa, Universitas Islam Negeri Raden Mas Said Surakarta. Email: wahyunurkhasanah69@gmail.com

${ }^{3}$ Fakultas Adab dan Bahasa, Universitas Islam Negeri Raden Mas Said Surakarta. Email: ghonimiatin697@gmail.com
} 
Volume 2, Nomor 2, Desember 2021

\section{PENDAHULUAN}

Semua orang membutuhkan bahasa untuk dapat berkomunikasi. Hal ini sejalan dengan pendapat Amri (Hermawan, dkk: 2020: 116) yang menyatakan bahwa bahasa adalah alat yang dijadikan sesama manusia untuk berkomunikasi serta berinteraksi dengan adanya pertukaran berbagai simbol linguistik baik secara lisan maupun secara tulisan. Sebagai warga negara yang baik, kita harus dapat memahami dan menggunakan bahasa Indonesia secara baik dan benar. Oleh karena itu, mata pelajaran bahasa Indonesia telah diajarkan kepada peserta didik dibangku sekolah dasar. Tujuan pembelajaran bahasa Indonesia menurut Sudaryanto (Hermawan, dkk: 2020: 116) yaitu menjaga bahasa sendiri serta menyalurkan pengetahuan bahasa yang dibanggakan rakyat Indonesia.

Kesalahan berbahasa secara umum disebabkan oleh manusia yang memakai suatu bahasa bukan terletak pada bahasa yang dipakai. Menurut pendapat Tarigan (Hermawan, dkk:
2020: 116) kesalahan berbahasa ialah terjadinya penyimpangan kaidah kebahasaan dan tuturan yang dilakukan oleh pemakai bahasa baik secara lisan maupun tulisan. Menurut Setyawati (2010: 15-16) Berikut adalah beberapa alasan seseorang seseorang dapat mengalami kesalahan berbahasa diantaranya: (1) terbawa pengaruh oleh bahasa yang sebelumnya dikuasai,

ketidakpahaman pada bahasa yang digunakan, (3) bahasa yang diajarkan belum sempurna atau tepat.

Analisis kesalahan adalah sebuah proses berdasarkan terhadap analisis seseorang yang mengalami kesalahan saat tengah belajar bahasa yang telah ditargetkan. Target bahasa meliputi bahasa ibu, bahasa nasional, serta bahasa asing. Penelitian ini berfokus pada bahasa nasional. Penelitian ini mengkaji tentang analisis kesalahan sintaksis pada berita online yang diterbitkan oleh Solopos.com dengan judul Tradisi Sunatan Unik di Klaten, Bocah diarak dan dimandikan di Sendang yang ditulis oleh dka. Alasan dipilihnya berita tersebut karena masih banyak 
Volume 2, Nomor 2, Desember 2021

ditemukannya kesalahan sintaksis.

Dengan adanya penelitian ini diharapkan mampu mengungkapkan kesalahan sintaksis pada berita Tradisi Sunatan Unik di Klaten, Bocah diarak dan dimandikan di Sendang

\section{LANDASAN TEORI}

\section{Kesalahan Berbahasa Pada Tataran Sintaksis}

Menurut Ramlan (Permatasari, dkk, 2019: 106) yang dimaksud dengan sintaksis merupakan cabang ilmu bahasa yang mengkaji tentang keterkaitan wacana, klausa, frasa, serta kata. Menurut Suharyadi (Permatasari, dkk, 2019: 107) sintaksis diartikan sebagai sintansis merupakan ilmu bahasa yang sejak dahulu telah dikaji, kajian sintaksis berupa struktur kalimat dan kaidah penyusunan kalimat. Berdasarkan pendapat diatas dapat diartikan bahwa sintaksis adalah ilmu linguistik yang mengkaji tentang pembentukan kata baik kalimat, klausa, maupun frasa.
Samsuri (Permatasari, dkk, 2019: 107) berpendapat bahwa kesalahan sintaksis yaitu terjadinya sebuah penyimpangan struktur kalimat, klausa, frasa, dan tidak adanya ketepatan dalam menggunakan artikel.

\section{a. Kesalahan berbahasa dalam Frasa}

Menurut pendapat Malan (Permatasari, dkk, 2019: 107) kesalahan frasa dalam sintaksis terbagi menjadi 6 macam diantaranya:

1) Tidak tepat menggunakan preposisi.

Contohnya,'Ibu akan pergi di Pasar untuk berbelanja".

Pembenaran, "Ibu akan pergi ke Pasar untuk berbelanja".

\section{2) Terdapat Ketidaktepatan} Susunan Kata

Contohnya, "Kemari saya hadir untuk bertemu dengan ibu"

Pembenaran, "Saya hadir kemari untuk bertemu dengan ibu" 
Volume 2, Nomor 2, Desember 2021

3) Mengandung unsur yang Mubazir

Unsur yang mubazir dalam suatu kalimat menurut Malan (Permatasari, dkk, 2019: 107) penggunaan kata yang memiliki makna bersinonim dari suatu kalimat.

Contohnya, "Rita mundur kebelakang setelah menyelesaikan presentasinya" Pembenaran "Rita mundur setelah menyelesaikan presentasinya.

4) Terdapat Penjamakan Secara Ganda

Contohnya, "Para muridmurid tengah mengikuti ujian"

Pembenaran, "Para murid tengah mengikuti ujian"

5) Adanya pemakaian Bentuk Superlatif Secara

\section{Berlebihan}

Superlatif menurut Malan merupakan bentuk yang mempunyai makna paling.

Contohnya, "Gunung itu sangat tinggi sekali”

Pembenaran, "Gunung itu sangat tinggi”
6) Adanya pemakaian Bentuk Resiprokal yang Keliru

Malan (Permatasari, dkk, 2019: 107) berpendapat bahwa bentuk resiprokal dapat diartikan sebagai bentuk dengan makna berbalasan dalam suatu bahasa, bisa dengan kata berimbuhan atau dengan kata saling.

Contohnya, "Di hari lebaran kita saling bermaaf-maafan"

Pembenaran, ““'Di hari lebaran kita saling bermaafan"

\section{b. Kesalahan Sintaksis Berupa}

\section{Kalimat}

Menurut (Permatasari, dkk, 2019: 107) Wardani mengelompokkan kesalahan berbahasa dalam tataran sintaksis menjadi Sembilan yaitu.

1) Kalimat Ambigu. Seperti "Teman dokter cantik itu sedang melakukan pemeriksaan kesehatan" dengan kalimat awal "Teman dokter yang cantik itu sedang 
Volume 2, Nomor 2, Desember 2021

melakukan pemeriksaan kesehatan".

2) Kalimat Yang Tidak Jelas. Seperti "Tugas Mahasiswa adalah untuk terus belajar dan berusaha" dengan kalimat awal "Adalah merupakan tugas mahasiswa untuk terus belajar dan berusaha”.

3) Kalimat Berstruktur Tidak Baku. Seperti "Risa sangat beruntung jika Rio menjadi calon suami buat adiknya" dengan kalimat awal "Risa sangat beruntung jika Rio jadi calon suami buwat adiknya".

4) Kontaminasi Kalimat yang disebabkan tidak sesuainya dengan bahasa baku. Seperti "Jangan pernah pergi ketempat itu!" dengan kalimat awal "Jan pernah pergi ketempat itu!".

5) Diksi Yang Tidak Tepat dalam Membuat Kalimat. Seperti "Selamat datang di Museum Manusia Purba Sangiran" dengan kalimat awal "Selamat datang ke Museum Manusia Purba Sangiran".
6) Penggunaan Kata Mubazir. Seperti "Anita pergi ke toko buku dan membeli beberapa novel" dengan kalimat awal "Anita pergi ke toko buku dan Anita membeli beberapa novel".

7) Koherensi. Seperti "Mereka membahas kehendak rakyat" dengan kalimat awal "Mereka membahas daripada kehendak rakyat".

8) Logika Kalimat. Seperti "Bu Farida mengajarkan mata kuliah Manajemen Pendidikan" dengan kalimat awal "Bu Farida mengajar mata kuliah Manajemen Pendidikan".

9) Kata Serapan yang Digunakan dalam Kalimat. Seperti "Penemuan ini akan bermanfaat bagi semua orang" dengan kalimat awal "Dengan penemuan ini akan bermanfaat bagi semua orang".

\section{Ejaan}

Biasa dikenal dengan sebutan Ejaan Bahasa Indonesia yang 
Volume 2, Nomor 2, Desember 2021

Disempurnakan (EYD) yang sekarang menjadi Pedoman Umum Ejaan (Permatasari, dkk, 2019: 108) Bahasa Indonesia (PUEBI). Menurut Mulyanto pada tanggal 17 Agustus 1972 Ejaan Bahasa Indonesia yang Disempurnakan (EYD) diresmikan berdasarkan keputusan presiden nomor 57 tahun 1972. Fernandez dan Mukhlis hmembagi keslahan dalam ejaan menjadi empat jenis yaitu.

1) Kesalahan Penulisan Kata. Seperti "Jasa pemesanan barang itu hanya terjadi antar kota" dengan kalimat awal "Jasa pemesanan barang itu hanya terjadi antar kota".

2) Kesalahan Pemakaian Huruf. Seperti Pak Do menyampaikan , "Bahwa mulai besuk akan diadakan kelas pengayaan" dengan kalimat awal Pak Do menyampaikan, "bahwa mulai besok akan diadakan kelas pengayaan".

3) Kesalahan Ejaan Kombinasi.

Seperti "Kita jadi hangout kapan?" dengan kalimat awal "Kita jadi hangout kapan?"
4) Kesalahan Pemakaian Tanda

Baca. Seperti "Namun, hal itu akan membuat kesulitan bagi orang lain" dengan kalimat awal "Namun hal itu akan membuat kesulitan bagi orang lain".

\section{METODE PENELITIAN}

Penelitian ini tergolong sebagai penelitian kualitatif. Menurut Sugiyono (Ali, dkk,2021: 45) penelitian kualitatif merupakan penelitian yang berlandaskan pada filsafat postpositivitasme, dengan tujuan untuk bisa meneliti objek secara alamiah, pada penelitian ini peneliti menjadi instrumen kunci. Serta data penelitian dikumpulkan secara gabungan.

Penelitian ini menggunakan teknik baca dan teknik catat dengan langkah-langkah antara lain :

(1) Membaca berita online Tradisi Sunatan Unik di Klaten, Bocah diarak dan dimandikan di Sendang dengan teliti dan cermat.

(2) Mengidentifikasi kesalahan berbahasa pada berita online Tradisi Sunatan Unik di Klaten, 
Volume 2, Nomor 2, Desember 2021

Bocah diarak dan dimandikan di Sendang

(3) Mencatat hasil identifikasi kesalahan berbahasa pada berita online Tradisi Sunatan Unik di Klaten, Bocah diarak dan dimandikan di Sendang

(4) Mengelompokkan kesalahan berbahasa berdasarkan teori tataran sintaksis pada berita online Tradisi Sunatan Unik di Klaten, Bocah diarak dan dimandikan di Sendang

(5) Memaparkan kesalahan berbahasa berdasarkan tataran sintaksis pada berita online Tradisi Sunatan Unik di Klaten, Bocah diarak dan dimandikan di Sendang

(6) Menyimpulkan hasil penelitian.

\section{PEMBAHASAN}

Berdasarkan data yang telah ditemukan, ditemukan berbagai kesalahan dalam tataran sintaksis dan ejaan, seperti kesalahan diksi yang tidak tepat dalam membuat kalimat, kesalahan ejaan kombinasi, kalimat yang tidak jelas, kesalahan penulisan kata, dan kalimat berstruktur tidak baku.
1. Kesalahan Diksi Yang Tidak Tepat Dalam Membuat

\section{Kalimat}

Terdapat penggunaan diksi yang tidak tepat pada kutipan.

"Mandinya pun bukan mandi biasa, siswa di kelas V SDN II Kemiri itu melakukan ritual mandi kembali yang dilanjutkan tebar benih ikan."

Pada data di atas terdapat kesalahan pada penggunaan diksi yaitu pada kata di diganti dengan yang duduk di atau kata di dihilangkan karena ambigu.

\section{Kesalahan Berstruktur Tidak}

\section{Baku}

Terdapat penggunaan kata tidak baku pada kutipan.

"Biar sakitnya ke saya saja. Ini tradisi turun-temurun di sini."

Pada data di atas terdapat kata yang tidak baku yaitu biar yang seharusnya diganti dengan kata agar.

\section{Kalimat Yang Tidak Jelas}

Terdapat penggunaan kalimat yang tidak jelas pada kutipan.

"Apa sebab ia melakukan itu sетиа?" 
Volume 2, Nomor 2, Desember 2021

Kalimat tersebut menjadi tidak jelas karena urutannya yang belum tepat. Pembetulan kalimat di atas yaitu Sebab apa ia melakukan itu semua?.

\section{Kesalahan Ejaan Kombinasi}

Terdapat kesalahan ejaan kombinasi pada kutipan.

“....menebar kembang mawar di sendang tersebut."

Pada data di atas terdapat kesalahan pada kata kembang yang merupakan bahasa Jawa dari kata bunga. Seharusnya kata kembang ditulis dengan cetak miring.

“...kami berharap di sendang ini ora pedot banyune."

Pada data di atas terdapat campuran bahasa jawa yaitu kata ora pedot banyune yang seharusnya kata tersebut dicetak miring karena termasuk bahasa daerah.

“Kegiatan seerti memang sudah menjadi tradisi sejak zaman embah-embah dulu."

Pada data di atas, kata embahembah seharusnya dicetak miring karena termasuk bahasa daerah.

\section{Kesalahan Penulisan Kata}

Kesalahan penulisan kata terdapat pada kutipan.

“....kepada orang tuanya di depan ruma."

Pada data di atas terdapat kesalahan penulisan kata pada kata ruma yang seharusnya rumah.

\section{PENUTUP}

Dari hasil penelitian di atas dapat diambil berbagai kesimpulan bahwa masih terdapat kesalahan dalam tataran sintaksis dan ejaan dalam penulisan surat kabar online. Pada tataran sintaksis terdapat kesalahan diksi yang tidak tepat dalam membuat kalimat sebanyak 1 data, kesalahan berstruktur tidak baku sebanyak 1 data, kalimat yang tidak jelas sebanyak 1 data. Sedangkan kesalahan pada tataran ejaan terdapat kesalahan ejaan kombinasi sebanyak 3 data, dan kesalahan penulisan kata sebanyak 1 data.

\section{DAFTAR PUSTAKA}

Ali, F. F., Charlina, \& Septyanti, E. (2021). Analisis Kesalahan 
Volume 2, Nomor 2, Desember 2021

\begin{tabular}{lrr} 
Berbahasa & & Tataran \\
Sintaksis & Pada & Blog \\
Mahasiswa & \multicolumn{2}{r}{ Pendidikan } \\
Bahasa & Dan & Sastra \\
Indonesia & Angkatan & 2017 \\
Universitas & Riau. & Jurnal \\
Guru Kita , 44-50.
\end{tabular}

Hermawan, M. A., Ferawati, L., \& Citra, R. (2020). Analisis Kesalahan Bidang Sintaksis Pada Rubrik"KELUARGA" Surat Kabar Kedaulatan Rakyat Edisi 16 Februari 2020. Jurnal Piktorial , 115122.

Nur Endah Permatasari, I. M. (2019). Kesalahan Berbahasa

\author{
Dalam Majalah Pandawa \\ IAIN Surakarta Edisi 2018 \\ Pada Tataran Ejaan dan \\ Sintaksis. Diglosia , 103- \\ 114.
}

Permatasari, N. E., Khasanah, I. M., \& Putri, N. A. (2019). Kesalahan Berbahasa Dalam Majalah Pandawa IAIN Surakarta Edisi 2018 Pada Tataran Ejaan Dan Sintaksis. Diglosia , 103114.

Setyawati, N. (2010). Analisis Kesalahan Berbahasa. Surakarta: Yuma Pustaka. 